\title{
PUSTAKA APUNGKU SEBAGAI UPAYA PENINGKATAN LITERASI MASYARAKAT DI KAMPUNG NELAYAN KOTA MEDAN
}

\author{
Elvi Mailani ${ }^{*}$, Fahmy Syahputra ${ }^{2}$, Nora Ronita Dewi ${ }^{3}$ \\ ${ }^{1}$ Program Studi Pendidikan Guru Sekolah Dasar, Fakultas Ilmu Pendidikan, Universitas Negeri Medan, Medan, \\ Indonesia \\ ${ }^{2}$ Program Studi Pendidikan Teknik Elektro, Fakultas Teknik, Universitas Negeri Medan, Medan, Indonesia \\ ${ }^{3}$ Program Studi Pendidikan Bahasa Inggris, Fakultas Bahasa dan Seni, Universitas Negeri Medan, Medan, \\ Indonesia \\ *Penulis korespondensi: elvimailani@gmail.com
}

\begin{abstract}
Abstrak
Mitra yang menjadi sasaran Kegiatan Pengabdian Penerapan Teknologi Tepat Guna adalah Perpustakaan Terapung Kampung Nelayan Seberang, Belawan, Provinsi Sumatera Utara dan SD Negeri 068009 Belawan. Berdasarkan observasi dan wawancara terdapat 4 masalah utama yang dihadapi mitra, antara lain: (1) ruangan perpustakaan yang tidak luas, (2) penataan buku terkesan berantakan, (3) kegiatan di perpustakaan hanya sebatas membaca buku dan (4) administrasi peminjaman buku yang masih manual. Berdasarkan permasalahan tersebut ditawarkan solusi,: (1) pendampingan penataan ruangan dan penyusunan buku, (2) pendampingan membuat rak buku yang lebih kuat dan efesien, (3) pengadaan gerobak pintar yang dapat berpindah-pindah, (4) pendampingan dan workshop dalam meningkatkan keterampilan literasi siswa, dan (5) membangun aplikasi perpustakaan terapung dan pangkalan data online. Target khusus dan luaran yang akan dihasilkan: (1) ruangan perpustakaan yang kesannya jadi lebih luas, (2) rak buku yang lebih kuat dan jumlah buku yang lebih banyak, (3) Gerobak Pintar (4) alat peraga bahasa,kumpulan syair dan melodi lagu wajib beserta alat musiknya, alat peraga sains dan matematika, dan (5) aplikasi untuk pengelolaan administrasi perpustakaan yang disebut "Aplikasi Pustaka Apungku". Metode pelaksanaan program pengabdian akan dilakukan secara bertahap, berkelanjutan, dan komprehensif yang dilaksanakan melalui metode pendampingan dan workshop.
\end{abstract}

Kata kunci: Literasi; Integrase; Pustaka Apungku; Pendampingan.

\begin{abstract}
The partners who were targeted in the Appropriate Service Technology Application Activities were the Floating Library of the Seberang Fishermen Village, Belawan, North Sumatra Province and Belawan State Elementary School 068009. Based on observations and interviews, there are 4 main problems faced by partners, including: (1) library space that is not spacious, (2) book arrangement seems messy, (3) library activities are limited to reading books and (4) book loan administration still manual. Based on these problems, solutions are offered: (1) room management and book arrangement assistance, (2) assistance to make bookshelves more powerful and efficient, (3) procurement of mobile carts that can move around, (4) assistance and workshops in improving student literacy skills, and (5) building floating library applications and online databases. Specific targets and outputs that will be produced: (1) library room that seems to be more spacious, (2) stronger bookshelves and a greater number of books, (3) Smart Carts (4) language props, poetry collections and melodies compulsory songs with their musical instruments, science and mathematics teaching aids, and (5) applications for library administration management called "Apungku Library Application". The method of implementing the service program will be carried out in stages, in a sustainable, and comprehensive manner through the assistance and workshop methods.
\end{abstract}

Keywords: Literacy; Integrase; Pustaka Apungku; Accompaniment.

\section{PENDAHULUAN}

Perpustakaan adalah sekumpulan bahan pustaka, baik yang tercetak maupun rekaman yang lainnya, pada suatu tempat tertentu yang telah diatur sedemikian rupa untuk mempermudah pemustaka mencari informasi yang diperlukannya dan yang tujuannya utamanya adalah untuk melayani kebutuhan informasi masyarakat yang dilayaninnya dan bukan untuk diperdagangkan. (Sinaga 2005). Selanjutnya Yunaldi (2012) mengatakan bahwa fungsi dari perpustakaan adalah sebagai wadah untuk: 
(1) pusat pendidikan, (2) pusat rekreasi, (3) pusat penelitian, (4) pusat informasi.

Mitra satu yang menjadi sasaran program Penguatan Program Literasi Berbasis Integrasi Aplikasi dan Pangkalan Data adalah Perpustakaan Terapung. Perpustakaan terapung ini berada di Kampung Nelayan Sebrang Belawan I Medan Sumatera Utara. Perpustakaan Terapung ini adalah wadah bagi masyarakat kampong nelayan dalam mendapatkan sarana informasi dan berbagai hal pengetahuan yang sangat berguna bagi sebagian besar masyarakat yang berada di Kampung Nelayan. Perpustakaan terapung ini berdiri sejak 26 Januari 2016, dengan penanggung jawab yayasan Bangun Bahari Sidik Hermawan. Perpustakaan terapung ini memiliki 1000 buku yang merupakan sumbangan dari mahasiswa dan masyarakat peduli pendidikan lainnya.

Karena letaknya didaerah pesisir dan diatas laut, banyak permasalahan yang dihadapi oleh perpustakaan terapung ini. Perpustakaan yang awalnya di atas laut dikarenakan keadaan fisik yang tidak mendukung, akhirnya rubuh dan tidak dapat dimanfaatkan lagi. Sampai saat ini perpustakaan terapung ini belum memiliki tempat yang permanen sehingga keberadaan perpustakaan ini berpindah-pindah dengan menyewa ruangan dari rumah penduduk maupun sekolah. Saat ini perpustakaan terapung ini memanfaatkan bangunan milik kepala dusun kampung nelayan tersebut. Gambaran kondisi Perpustakaan Terapung dapat dilihat pada gambar berikut:

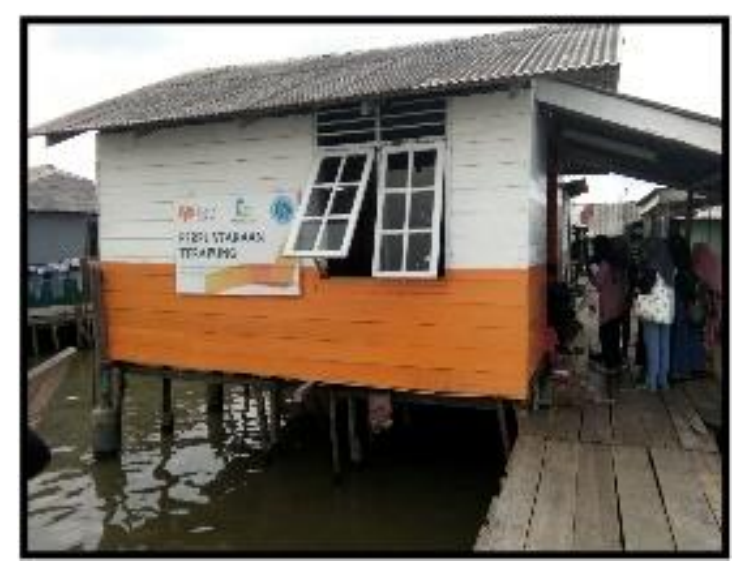

Gambar 1. Perpustakaan Terapung.

Sarana dan prasarana yang terdapat di Perpustakaan Terapung sangat memprihatinkan dan seadanya saja. Hanya sebatas buku yang diletakkan pada lemari dan rak buku yang sebagian besar sudah tidak layak pakai karena keadaannya yang sudah lapuk disebabkan dimakan rayap dan terkena paparan air hujan. Selain itu seluruh lemari dan rak buku tidak tertata dengan baik. Keadaan penataan dan kondisi sarana dan prasarana tersebut membuat ruangan yang sempit semakin terlihat menjadi lebih sempit dan menyebabkan ruangan tersebut menjadi tidak dapat dimanfaatkan dengan maksimal. Gambaran keadaan sarana dan prasarana
Perpustakaan Terapung dapat dilihat pada gambar berikut:

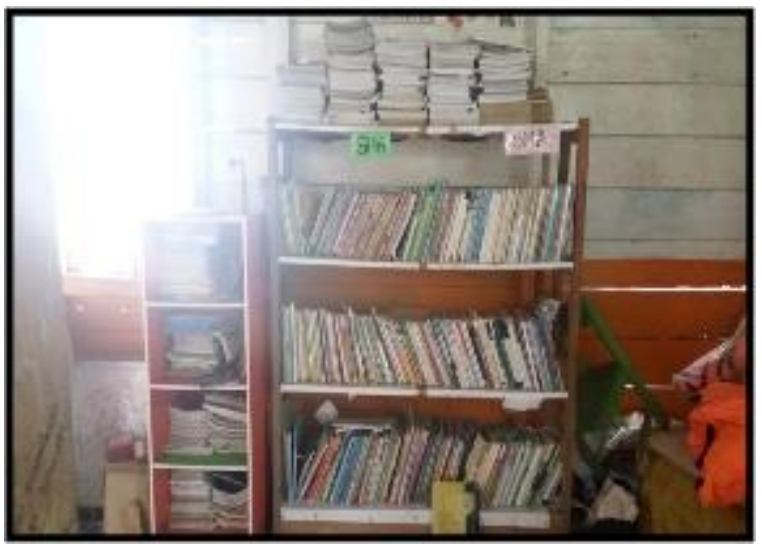

Gambar 2. Sarana perpustakaan Terapung.

Pemanfaatan perpustakaan saat ini juga baru hanya sebatas untuk tempat aktivitas membaca saja, dan belum mampu menjadi tempat untuk menggali kemampuan dan keterampilan siswa yang lain seperti keterampilan, seni budaya, sains dan keterampilan matematika dan kegiatan lainnya sehingga kegiatan di perpustakaan kesannya sangat monoton.

Perpustakaan ini juga belum memiliki akses internet yang merupakan salah satu sumber informasi yang terupdate sehingga informasi-informasi terbaru sulit diakses oleh masyarakat yang memanfaatkan perpustakaan ini. Selain itu system administrasi di Perpustakaan Terapung ini masih bersifat manual, sehingga susah untuk mengontrol keadaan dan keberadaan buku dikarenakan tidak akuratnya informasi pengguna dan keadaan buku yang terdapat di perpustakaa

Sekolah yang menjadi mitra 2 dari pengabdian ini adalah SDN 068009 Kampung Nelayan, yang beralamat di Kampung Nelayan Belawan Kota Medan. Sekolah ini merupakan sekolah yang terdekat dengan Perpustakaan Terapung sekolah ini memiliki 12 rombel dengan jumlah guru sebanyak 12 guru dan siswa sebanyak 370 orang.

Kampung Nelayan merupakan sebuah wilayah dimana lingkungan masyarakat yang sebagian besar mata pencahariannya sebagai nelayan, memiliki jumlah siswa sekolah yang cukup besar, dan keinginan belajar siswanya untuk memperoleh pendidikan cukup tinggi, namun fasilitas pendidikan dan sanggar belajar yang sangat terbatas. Kampong nelayan memiliki 2 TK dan 1 SD dan pola asuh sebagian besar orang tua cenderung kurang baik terutama yang berhubungan dengan pendidikan. Orang tua di kampong nelayan kurang meluangkan waktu untuk perkembangan anak, baik pada bidang social, pendidikan dan kebutuhan lain (shiddiq, 2018).

Berdasarkan hasil observasi dan wawancara yang dilakukan, maka permasalahan yang menjadi prioritas 
utama yang harus segera diselesaikan ada 4 hal, yaitu sebagai berikut:

1) Tempat yang terbatas sehingga tidak dapat menampung keseluruhan anak/siswa untuk memperoleh pengetahuan pada waktu yang sama. Selain itu lokasi Perpustakaan Terapung yang sulit dijangkau secara bersamaan oleh warga masyarakat kampong nelayan.

2) Penataan buku yang terkesan apa adanya, tidak teratur, sarana penunjang buku yang tidak memadai jumlah buku yang sangat terbatas

3) Aktivitas kegiatan yang dilakukan di perpustakaan hanya sebatas membaca buku saja tanpa ada kegiatan keterampilan lainnya, sementara aktivitas yang dilakukan guru dalam mengajar hanya sebatas ceramah, menggunakan buku paket tanpa menggunakan alat peraga/ media dalam proses pembelajarannya

4) Administrasi dan manajemen pengaturan peminjaman buku yang masih bersifat manual sehingga menyulitkan pengurus mengontrol jumlah, judul buku dan keberadaan buku di perpustakaan.

\section{METODE}

Tahapan penerapan teknologi kepada masyarakat program Penguatan Program Literasi Berbasis Integrasi Aplikasi dan Pangkalan Data Kampung Nelayan Seberang, Belawan, Provinsi Sumatera Utara, dilaksanakan berdasarkan permasalahan-permasalahan yang dilihat dan dijumpai pada perpustakaan terapung yang menjadi mitra pada program ini. Dalam upaya mencapai tujuan kegiatan Penguatan Program Literasi Berbasis Integrasi Aplikasi dan Pangkalan Data, maka rancangan pada kegiatan ini adalah perencanaan (planning), pelaksanaan (action), refleksi (reflection) dan tindak lanjut (follow up).

Kegiatan perencanaan dilakukan melalui aktivitas identifikasi awal yaitu melakukan identifikasi kebutuhan yang meliputi kegiatan: (1) observasi awal yang menghasilkan profil mitra yang menjadi sasaran kegiatan, (2) identifikasi permasalahan yang menghasilkan dokumen permasalahan, dan (3) identifikasi solusi yang menghasilkan alat dan spesifikasi dalam penyelesaian masalah. Kegiatan pelaksanaan dilakukan melalui kegiatan workshop dan pendampingan yang menghasilkan berbagai luaran yang sangat dibutuhkan oleh mitra dalam mengatasi permasalahan yang telah diuraikan. Refleksi dilakukan diakhir kegiatan bertujuan untuk melihat kelemahan dan kekurangan dari kegiatan proses dan hasil yang telah dilakukan serta luaran yang dihasilkan untuk mendapatkan hasil yang maksimal sesuai dengan apa yang direncanakan pada kegiatan ini. Kegiatan tindak lanjut dilakukan untuk memperkuat mitra dalam mengembangkan dan mengimbaskan seluruh program dan kegiatan yang telah diberikan ke jenjang yang lebih luas lagi.

Adapun gambaran metode pelaksanaan kegiatan, seperti tertera pada bagan berikut:

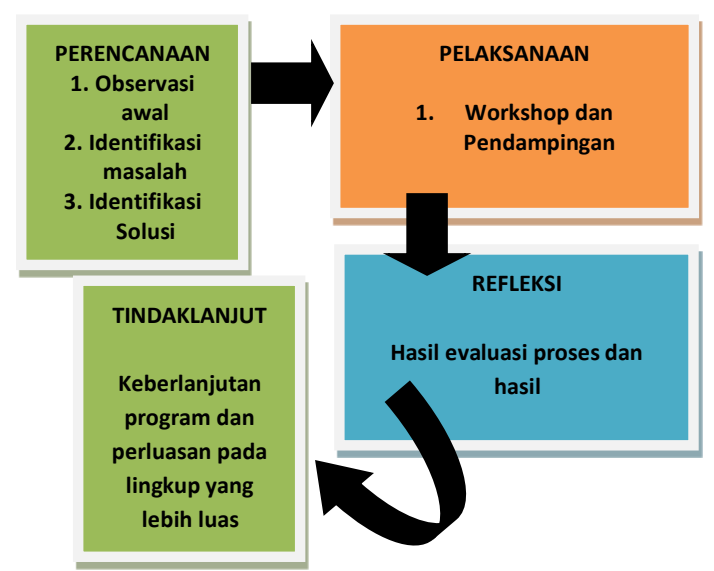

Gambar 3. Metode Pelaksanaan

\section{HASIL DAN PEMBAHASAN}

\subsection{Tempat yang terbatas}

Berdasarkan permasalahan yang telah disepakati dan diidentifkasi oleh tim dan mitra kegiatan, salah satu masalah yang harus dicarikan solusinya adalah masalah Tempat yang terbatas sehingga tidak dapat menampung keseluruhan anak/siswa untuk memperoleh pengetahuan pada waktu yang sama. Selain itu lokasi Perpustakaan Terapung yang sulit dijangkau secara bersamaan oleh warga masyarakat kampong nelayan, maka solusi yang dilakukan adalah mengatur penyusunan rak buku dan sarana dan prasarana perpustakaan sehingga adanya ruang yang lebih luas yang dapat menampung anak-anak untuk belajar diperpustakaan.

Selain itu untuk mengatasi keterbatasan ruangan dan untuk memaksimalkan buku-buku yang terdapat di perpustakaan terapung, maka dibuatlah gerobak pintar yang dapat berpindah tempat sehingga masyarakat kampong nelayan yang tidak dapat hadir ke Perpustakaan terapung, dapat juga merasakan keberadaan perpustakaan terapung tersebut melalui gerobak pintar yang dapat perpindah-pindah tempat. Luaran dari solusi ini adalah: (1) ruangan perpustakaan yang tertata lebih luas dan nyaman sehingga membuat semangat siswa dan masyarakat dalam memanfaatkan perpustakaan sekolah dan perpustakaan terapung, (2) gerobak Pintar yang dilengkapi dengan penghancur kertas dan cas hp bertenaga solar sel serta berbagai permainan edukatif bagi siswa SD dan PAUD. 


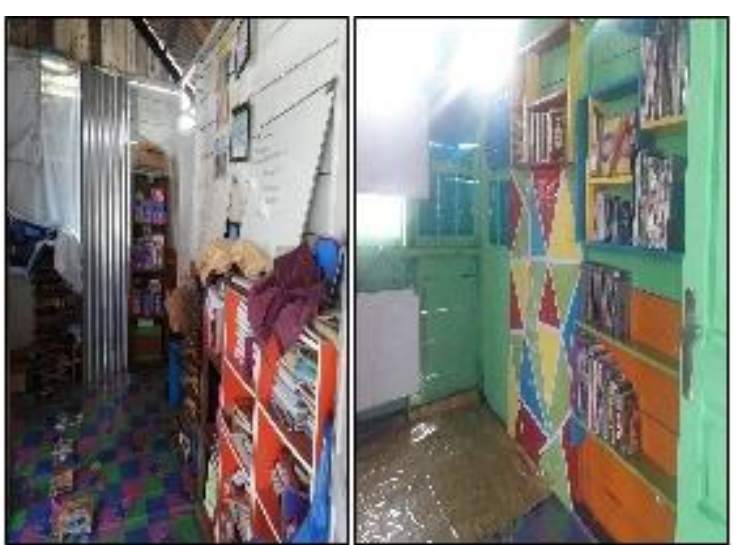

Gambar 4. Kondisi Ruangan Sebelum dan sesudah Kegiatan.

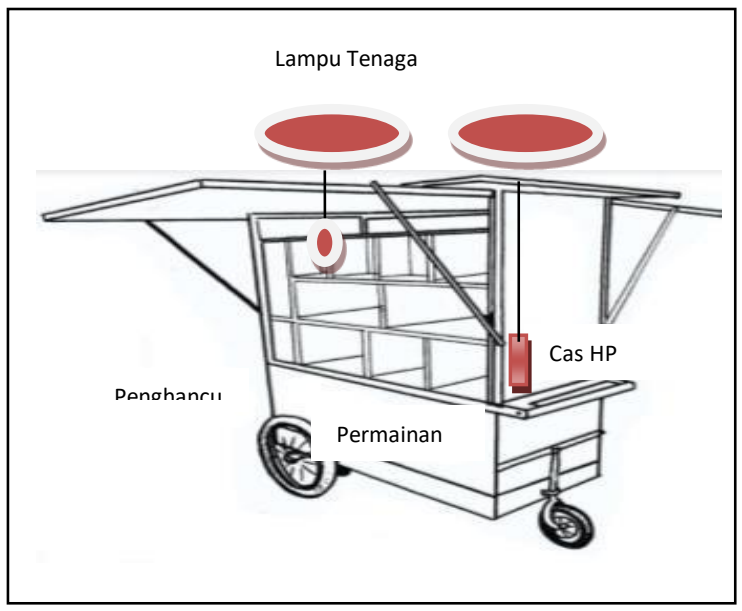

Gambar 5. Gerobak Pintar.

\subsection{Penataan buku}

Masalah Penataan buku yang terkesan apa adanya, tidak teratur, sarana penunjang lain seperti rak buku yang tidak memadai, sangat terbatas, dan sudah lapuk sehingga tidak memungkinkan untuk disusun banyak buku. Dampak dari keadaan ini sehingga masih banyak buku yang ditumpukkan pada sudut-sudut tertentu pada perpustakaan terapung. Selain itu banyak buku yang masih disimpan dalam kardus sehingga buku buku tersebut rusak dimakan rayap dan akibat tempias air hujan, buku terseut menjadi robek dan tidak dapat terpakai lagi. Solusi yang dilakukan untuk mengatasi permasalahan tersebut adalah membuat rak buku yang lebih kuat dengan bahan yang lebih baik sehingga memiliki ketahanan yang lebih lama dan tidak mudah rusak. Luaran dari solusi ini adalah rak buku yang kuat, tertata dengan baik sehingga ruangan perpustakaan menjadi lebih rapi dan terkesan lebih luas.

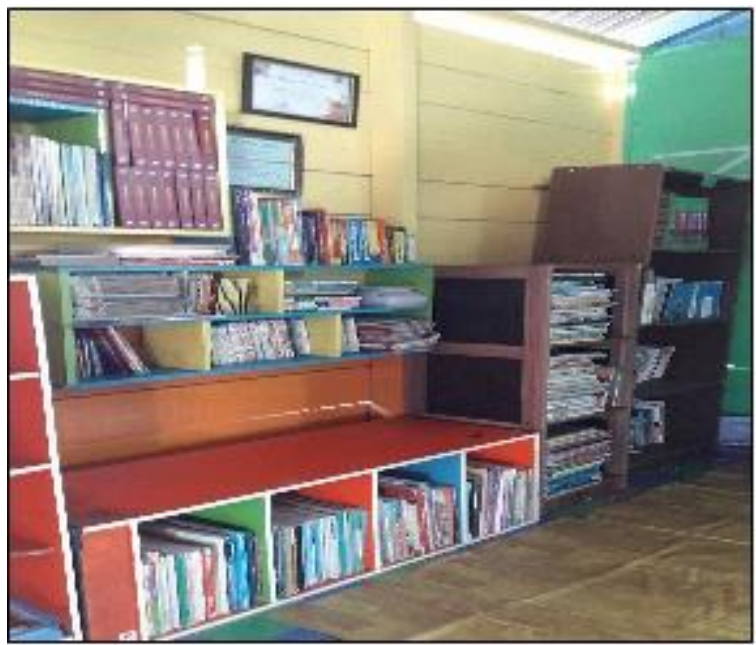

Gambar 5. Rak Buku Hasil Kegiatan.

\subsection{Aktivitas Kegiatan Perpustakaan Terapung}

Masalah Aktivitas kegiatan yang dilakukan di perpustakaan hanya sebatas membaca buku saja tanpa ada kegiatan keterampilan lainnya, solusi yang dilakukan adalah: (1) melakukan kegiatan yang bersifat menumbuhkan keterampilan berbahasa, seni budaya siswa, (2) melakukan kegiatan yang dapat melatih kemampuan sains dan matematika siswa. Luaran dari solusi ini adalah: (1) Kumpulan syair dan melodi lagulagu wajib beserta alat musiknya, (2) media pembelajaran matematika, IPA, dan bahasa Indonesia.

1) Kegiatan menumbuhkan keterampilan berbahasa dan seni budaya

Kegiatan ini dilakukan melalui aktivitas latihan dan pendampingan membuat boneka dengan memanfaatkan kertas bekas yang terdapat di perpustakaan terapung. Kertas-kertas bekas yang dihancurkan di Perpustakaan Terapung diolah untuk membuat boneka dan berbagai media pembelajaran lainnya. Selain membuat boneka dan berbagai media lainnya, kegiatan workshop dan pendampingan juga memberikan bekal kepada guru dan pengelola Perpustakaan Terapung dalam hal meningkatkan kemampuan keterampilan berbahasa anak-anak pengguna perpustakaan terapung dengan cara memanfaatkan boneka dan media yang telah dibuat menjadi sarana dan media berkomunikasi.

Untuk keterampilan seni budaya kegiatan yang dilakukan adalah melatih dan mendampingi anak-anak pengguna Perpustakaan Terapung menggunakan alat music pianika yang telah dimodifikasi menjadi alat music yang dapat dengan mudah dimainkan oleh siapa saja tanpa harus menghafal nada dan not music. Dengan kemudahan memainkan alat music yang dirancang pada kegiatan ini, diharapkan minat dan semangat anak-anak pengguna Perpustakaan Terapung dalam hal seni dan budaya akan jauh lebih meningkat. Lagu-lagu yang dilatihkan kepada anak-anak pengguna Perpustakaan Terapung adalah lagu-lagu wajib dan lagu daerah yang sering didengar. Hasil dari kegiatan latihan dan pendampingan ini, anak-anak pengguna Perpustakaan Terapung mampu memainkan alat music pianika dengan baik. 


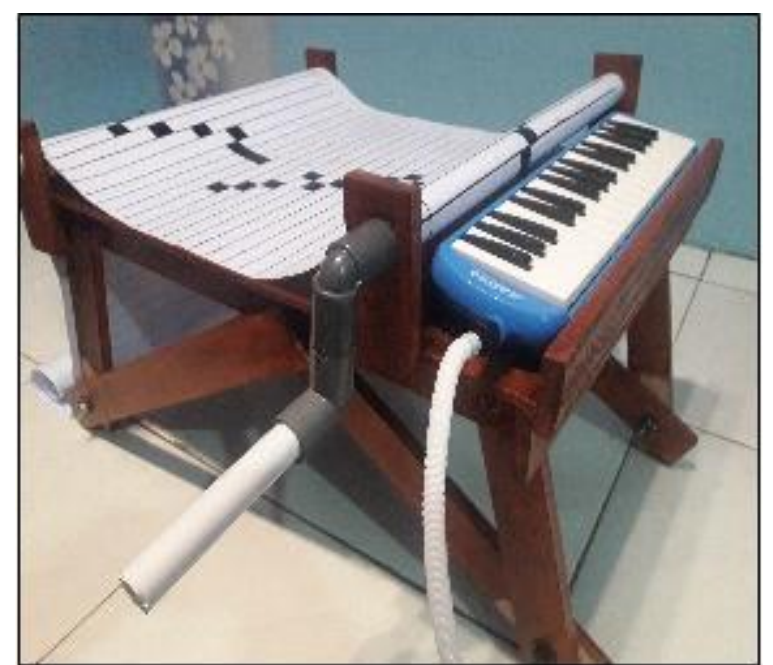

Gambar 6. Alat Musik Melodi Pianika.

2) Kegiatan yang dapat melatih kemampuan sains dan matematika siswa

Kegiatan pelatihan dan pendampingan ini dilakukan melalui berbagai aktivitas diantaranya dengan membuat alat peraga dan media pembelajaran sains dan matematika yang dapat membantu mempermudah pemahaman sains dan matematika anak-anak pengguna Perpustakaan Terapung dengan memanfaatkan berbagai bahan sederhana. Setelah media dan alat peraga tersebut dibuat, selanjutnya kegiatan dilanjutkan dengan memberikan pendampingan, kepada pengelola Perpustakaan Terapung dan guru-guru bagaimana pemanfaatan media dan alat peraga yang telah dirancang dan dibuat, dalam upaya memberikan kemudahan pemahaman konsep materi sains dan matematika sehingga dengan menggunakan media-media tersebut, anak-anak pengguna Perpustakaan Terapung dapat meningkatkan pengetahuannya pada bidang sains dan matematika.

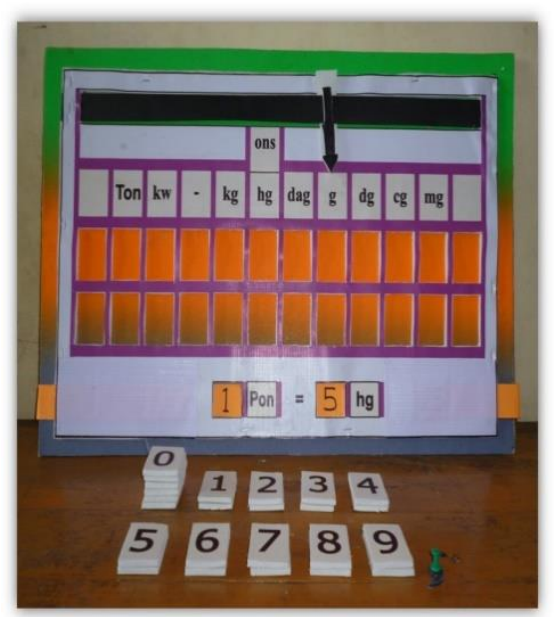

Gambar 7. Media/alat peraga matematika.

\subsection{Administrasi Perpustakaan Terapung}

Masalah administrasi dan manajemen yang merupakan permasalahan mitra kegiatan adalah pengaturan peminjaman buku yang masih bersifat manual, sehingga banyak buku yang tidak teridentifikasi dengan baik sehingga menjadikan kendala saat anak-anak pengguna Perpustakaan Terapung ingin memanfaatkan perpustakaan tersebut. Salah satu dampak dari administrasi yangmanual dan tidak teratur, keberadaan buku perpustakaan banyak yang tidak dikembalikan lagi setelah dipergunakan sehingga jumlah buku di Perpustakaan Terapung terus berkurang.

Solusi yang dilakukan untuk mengatasi permasalahan mitra ini adalah dengan merancang sebuah aplikasi yang diberi nama "Pustaka Apungku". Selanjutnya pengelola Perpustakaan Terapung diberikan pelatihan dalam penggunaan aplikasi perpustakaan online berbasis android yang membantu dalam hal pengaturan dan manajemen buku di Perpustakaan Terapung. Selain itu kegiatan dilanjutkan dengan pendampingan bagi pengelola Perpustakaan Terapung dan perpustakaan SDN 068009 Kampung Nelayan kota Medan dalam hal pembuatan catalog perpustakaan berbasis IT. Setelah dilakukan pelatihan dan pendampingan bagi pengelola Perpustakaan Terapung dan pengelola perpustakaan SDN 068009 Kampung Nelayan kota Medan, terlihat pengelolaan perpustakaan menjadi jauh lebih baik dan teratur. Luaran yang dihasilkan adalah : (1) aplikasi android pustaka apungku, dan (2) catalog buku berbasis IT.

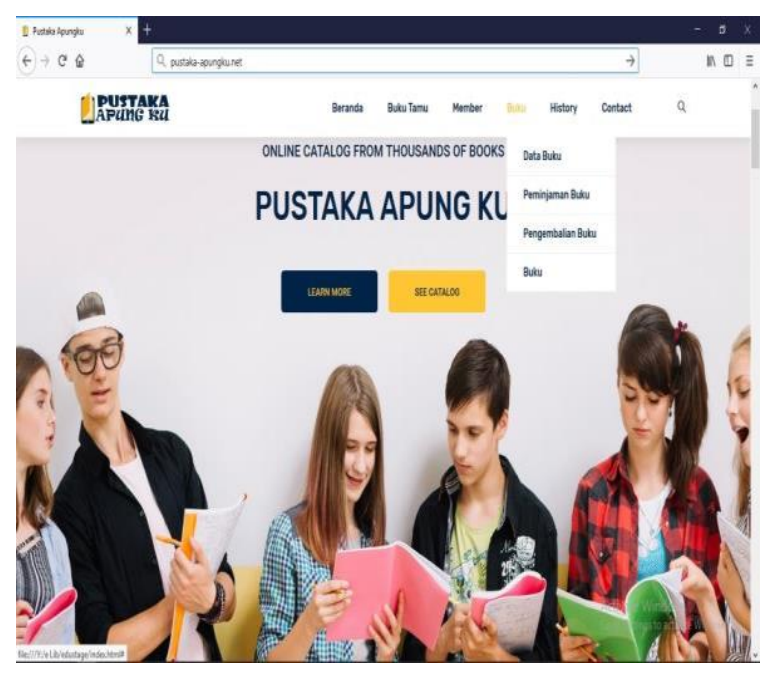

Gambar 8. Aplikasi Pustaka Apungku.

\section{KESIMPULAN}

Setelah dilaksanakan kegiatan di Perpustakaan Terapung dan perpustakaan SDN 068009 Kampung Nelayan kota Medan maka simpulan yang dapat dibuat adalah:

1) Tempat/ruangan Perpustakaan Terapung yang terbatas dapat termanfaatkan secara maksimal dikarenakan penataan ruangan Perpustakaan Terapung dan perpustakaan SDN 068009 Kampung Nelayan kota Medan menjadi lebih baik dan teratur.

2) Pembuatan rak buku yang lebih kuat, teratur dan baik sehingga dapat menampung buku-buku yang terdapat di Perpustakaan Terapung yang sebelumnya hanya ditumpukkan pada pojok tertentu, ataupun 
hanya diletakkan di dalam kardus sehingga kesan ruangan di Perpustakaan Terapung dan perpustakaan SDN 068009 Kampung Nelayan kota Medan yang tadinya sempit menjadi lebih luas.

3) Pengadaan 2 ( dua) Gerobak Pintar yang dapat mendekatkan buku dan referensi lain kepada warga masyarakat Kampung Nelayan kota Medan yang selama ini sulit untuk datang ke Perpustakaan Terapung disebabkan berbagai kesibukan dan alasan yang lain.

4) Peningkatan aktivitas di Perpustakaan Terapung yang tadinya hanya sebagai tempat untuk membaca saja, menjadi sebuah wahana untuk meningkatkan keterampilan anak-anak Kampong Nelayan pada bidang bahasa, seni budaya, sains dan matematika melalui kegiatan pembuatan berbagai media pendukung pembelajaran menggunakan barangbarang bekas dan latihan secara teratur.

5) Pembuatan aplikasi android "Pustaka Apungku" yang sanagat membantu pengelola Perpustakaan Terapung dan perpustakaan SDN 068009 Kampung Nelayan kota Medan dalam mengatur administrasi buku serta pembuatan katalok perpustakaan berbasis IT.

\section{UCAPAN TERIMA KASIH}

Ucapan terima kasih ditujukan kepada: Dr. Sofian Tan, Rektor Universita Negeri Medan, Ketua LPPM UNIMED, Kepala sekolah SDN 068009 Kampung Nelayan kota Medan, Tim Relawan Pustaka Terapung, dan Tim PPTTG.

\section{DAFTAR PUSTAKA}

Sinaga, D. (2005). Perpustakaan Masyarakat. Jakarta: Kreasi Media Utama.

Novriliam, R., \& Yunaldi, Y. (2012). Pemanfaatan Perpustakaan Sekolah Sebagai Pusat Sumber Belajar di Sekolah Dasar Negeri 23 Painan Utara. Ilmu Informasi Perpustakaan dan Kearsipan, 1(1), 141-150.

Shiddiq, M. (2018). Pola Asuh Orangtua Pada Pendidikan Agama Anak di Kampung Nelayan Seberang Kecamatan Medan Belawan (Doctoral dissertation, Universitas Islam Negeri Sumatera Utara). 